\title{
Correlation of Serum Ferritin with Components of Metabolic Syndrome and its Relationship with the Insulin Resistance in Men and Women
}

Boinapalli Sudhakar* and Shah Rita M

Department of Clinical Biochemistry, SBKS Medical College, Sumandeep Vidyapeeth, Piparia, Vadodara, Gujarat, India

\begin{abstract}
Background: Raised serum ferritin levels are associated with insulin resistance, type 2 diabetes mellitus, prediabetic stage, metabolic syndrome (Mets) and cardiovascular risk. The association between Serum ferritin and $\mathrm{HbA} 1 \mathrm{c}$ levels with individual components of metabolic syndrome and obesity are unclear.

Objectives: The present study was designed to investigate the relationship between serum ferritin levels, fasting Blood glucose levels, waist Hip ratio, fasting insulin levels, homeostasis model assessment (HOMA-IR), and lipid profile in previously diagnosed type 2 diabetes mellitus patients, newly diagnosed patients, impaired fasting glucose subjects and healthy subjects and relationship among iron stores, the metabolic syndrome, and insulin resistance in premenopausal women, postmenopausal women and men.
\end{abstract}

Subjects and methods: 1058 participants included in this study out of them 365 patients with previously diagnosed type 2 diabetes mellitus having poor glycemic control and good glycemic control, 144 patients with newly diagnosed type 2 diabetes mellitus, 189 participants with impaired fasting glucose levels and 360 healthy participants. Fasting blood glucose, Serum ferritin, serum insulin, $\mathrm{HbA} 1 \mathrm{c}$ waist hip ratio, and lipid parameters were estimated and Homeostasis Model Assessment-Insulin resistance (HOMA-IR) was calculated.

Results: Dichotomizing ferritin concentration in to $<300$ and $>300 \mathrm{ng} / \mathrm{ml}$ for men and $<150$ and $>150 \mathrm{ng} / \mathrm{ml}$ for women, the odd ratios for newly diagnosed diabetes were 4.94 (95\% Cl 3.05-8.01) for men 3.61 (2.01-6.48) for women. All multiple linear regression coefficients between ferritin concentration and concentration of insulin, glucose, and glycosylated hemoglobin were positive and significant for men and postmenopausal women.

Conclusion: On basis of present studies results, it is concluded that hyperferritinaemia and iron overload may be the primary cause of insulin resistance and metabolic syndrome before overt type 2 diabetes mellitus.

\section{Keywords: Mets; GHB; HOMA-IR}

Abbreviations: Mets: Metabolic syndrome; GHB: Glycosylated hemoglobin; HOMA-IR: Homeostasis model assessment-insulin resistance

\section{Introduction}

India is leading country in the globe with larger number of diabetic patients earning the dubiously distinction and termed the "capital of diabetes in the world". The type 2 diabetes mellitus is predicable to approximately double in prevalence in year between 2000 and 2030, with India having largest number of type 2 diabetes patients of any nation [1]. The prevalence of type 2 diabetes mellitus in India was estimated to be $7.8 \%$ in 2010 for a total of roughly 51 million people in accordance with International Diabetes Federation (IDF) Diabetes Atlas. Considering World Health Organization Criteria the earlier study in urban India showed even higher prevalence (12.1\%) [2]. It is expected that type 2 diabetes rise to $9.3 \%$ by year 2030 with increase in percentage of Indians, the reasons might include migration of human beings from rural to urban areas with change in dietary habits, and the shift to an increasingly sedentary lifestyle [3].

Increased Iron Stores can Causes type 2 diabetes patients with hemochromatosis [4]. However, it is not clear whether moderately elevated iron stores predict the risk of developing type 2 diabetes mellitus among healthy respondents. The free iron which carries unstable electrons produces hydroxyl radicals, which are powerful pro-oxidants that lysis the lipid cellular membrane, damages protein structural configuration, and displaces nucleic acids in genes $[5,6]$.

Previous studies gives about detailed hypothesis on the free iron catalyses to hydroxyl free radicals contributes initially to insulin resistance and subsequently to decreased insulin secretion and then to the development of type 2 diabetes mellitus [7-9]. Previous findings from cross-sectional or case control studies showed the association between increased serum ferritin concentration and insulin resistance with risk to type 2 diabetes mellitus have been inconsistent. Several of these studies observed positive associations [9-13].

However, moderate increase in serum iron stores concentrations may reflect systemic inflammation coexisting with the insulin resistance rather than high iron stores because blood samples are collected after the diagnosis of diabetes. Also, the directionality of the associations cannot be established based on retrospective or cross-sectional data.

The influence of iron metabolism and type 2 Diabetes had disclosed with the emerging scientific evidences. Glucose metabolism effects on several iron metabolic pathways the relationship is bi-

*Corresponding authors: Sudhakar B, Associate professor, Department of Biochemistry, PIMS, Umarda, Udaipur, Rajasthan 313015, India, Tel: 9672459809 ; E-mail: boinapallisudhakar@gmail.com

Received December 11, 2015; Accepted December 21, 2015; Published December 28, 2015

Citation: Sudhakar B, Rita MS (2016) Correlation of Serum Ferritin with Components of Metabolic Syndrome and its Relationship with the Insulin Resistance in Men and Women. Clin Med Biochem Open Access 2: 109. doi:10.4172/2471-2663.1000109

Copyright: ( $) 2016$ Sudhakar B, et al. This is an open-access article distributed under the terms of the Creative Commons Attribution License, which permits unrestricted use, distribution, and reproduction in any medium, provided the original author and source are credited. 
directional. Inflammatory cytokines in oxidative stress influences these relationships, replicates and intensifying the initiated events. Chronic diabetes complications are modulated by iron induced damage. In therapeutic measurements of large clinical trials in type 2 diabetes mellitus patients showed decreased iron toxicity [14].

To find out the hypothesis in which higher iron stores may predict to development of type 2 diabetes, we Consecrated this large cross sectional study to find out the biomarkers reflecting iron stores, including serum ferritin concentration in relation to the impairing glucose utilization by insulin resistance which lead to the development of type 2 diabetes in healthy men and women of age 30-65 years.

\section{Materials and Methodology}

\section{Enrollment of participant}

The Study initiated and started after Approval by Research Advisory Committee (RAC) and SBKS MI and RI Ethics committee. The participants willing to participate in the study had been explained about the purpose and method of the study, in their own language and their written informed consent taken. The Gujarati consent form enclosed. All participants asked to report, age, sex, alcohol intake, smoking, how often, on average, during the previous year they had consumed selected foods, beverages, and number of blood donations done, information is attached in case record form (CRF) annexure. Habitual alcohol consumption was inquired with the following two questions: "Do you drink alcohol at least once a month?" Yes/No.

\section{Study population}

The study conducted on participants and patients of age $>30-65$ years old men and women who visit to Dhiraj Hospital (DH) a territory Care 1226+Bedded Teaching hospital located in Pipariya, Vadodara to check for Diabetic Status and routine checkup. The present study was restricted to participant's women who were not pregnant at the time of examination. The excluded participants who had fasted $<8 \mathrm{~h}$ at the time of examination.

\section{Study period}

From August-2011 to September-2014.

\section{Study design}

Hospital based cross sectional study: In the study the participants are categorized into four groups based up on the new diagnostic criteria. These are Group-1 (Previously diagnosed case of type-2 DM), Group-2 (Newly Diagnosed type $2 \mathrm{DM}$ patients, fasting glucose concentration of $>7.0 \mathrm{mmol} / \mathrm{l}$ (>126 mg/dl),), Group-3 (Impaired fasting glucose subjects a fasting glucose concentration of 5.6 to $7.0 \mathrm{mmol} / \mathrm{l}(100-125$ $\mathrm{mg} / \mathrm{dl})$ ) and Group 4 (Healthy controls subjects fasting blood glucose concentration $<6.1 \mathrm{mmol} / \mathrm{l}(<110 \mathrm{mg} / \mathrm{dl}))$.

Based on the glycemic level (HbA1c), (previously diagnosed cases of diabetes mellitus patients were sub categorized into type 2 Diabetes mellitus with poor glycemic control $(>6.5 \%)$ and type 2 Diabetics mellitus with good glycemic control $(<6.5 \%)$.

\section{Physical examination}

BMI was calculated as weight in kilograms divided by the square of height in meters. Waist circumference was measured by a trained technician to the nearest $0.1 \mathrm{~cm}$ in the horizontal plane. At the level of the high point of the iliac crest at minimal respiration. Systolic and diastolic blood pressure (BP Syst, BP diast) were measured using a BP apparatus sphygmomanometer by physician in medicine OPD and diabetic clinic recorded in CRF form.

\section{Blood collection and biochemical methods}

All participants and patient samples collected at Dhiraj Hospital sample collection center. After checkup done by physician from Department of Medicine or Diabetic clinic send for blood analysis to Clinical lab. At least 8-10 ml of venous blood was collected from each volunteer after an overnight fast minimum $8 \mathrm{~h}$ fast without calorie intake ( $2 \mathrm{ml}$ into fluoride oxalate bottle for glucose analysis, $2 \mathrm{ml}$ into EDTA vaccutes for some haematological parameters like $\mathrm{Hb} \%$ and the remaining investigations lipid profile, CRP, fasting insulin levels into plain tubes. hematological analysis were carried out immediately from the EDTA vaccutes. Plain vaccutes was allowed to clot for 30 minutes and centrifuged $3000 \mathrm{rpm}$ for 15 minutes for clear separation of serum.

Blood glucose: The estimation of fasting blood glucose was carried out on an auto-analyzer -ERBA EM-200 Trans Asia. The method employed is an adaptation of the glucose oxidase peroxidase method (GOD POD method) [15].

Serum ferritin: The anti-ferritin antibody (rabbit) coated on the latex particles are agglutinated when mixed with samples containing ferritin. The agglutination causes an absorbance change dependent on the ferritin in the sample; this can be inter-plotted using a calibration curve prepared from calibrators of different concentrations [16, 17].

\section{HbA1C (Immuno Assay Nephlometry)}

This method utilizes the interaction of antigen and antibody to directly determine the HbAlc in whole blood. Total hemoglobin and HbAlc have the same nonspecific absorption rate to latex particle. When mouse antihuman HbAlc monoclonal antibodies is added (R2), HbA1c- mouse antihuman HbAlC antibody complex is formed. Agglutination occurs when goat anti-mouse IgG polyclonal antibody interacts with the monoclonal antibody. The amount of agglutination is proportional to the amount of $\mathrm{HbAlc}$ absorbed on to surface of latex particles. The amount of agglutination is measured to calculate HbAlc\% from a calibration curve [18-20].

Total cholesterol: Determined of Total cholesterol by CHOD-PAP Method [21,22].

Triglycerides: Estimation of Triglycerides by Glycerol phosphate oxidase (GPO) method [23-25].

\section{HDL-Direct (Immuno-inhibition)}

This estimation is based up on a modified coupled classic precipitation method by using the polyvinyl sulfonic acid (PVS) and polyethylene-glycol-methyl ether (PEGME) with the improvements in using optimized quantities of PVS/PEGME and selected detergents. LDL, VLDL, and chylomicron (CM) react with PVS and PEGME and the reaction results in inaccessibility of LDL, VLDL and CM by cholesterol oxidase (CHOD) and cholesterol esterase (CHER). The enzymes selectively react with $\mathrm{HDL}$ to produce $\mathrm{H}_{2} \mathrm{O}_{2}$ which is detected through a trinder reaction $[26,27]$.

\section{Insulin (ST AIA-PACK IRI is a two-site immune-fluro enzymometric assay)}

The immobilized monoclonal antibody coated with enzymelabeled on a magnetic solid phase binds with the insulin present in the test sample (Reagent AIA-PACK). The magnetic beads presented in the reagent pack are washed with buffer to remove unbound enzyme-labeled monoclonal antibody and are then incubated with a 
fluorogenic substrate; 4-methylumbelliferyl phosphate (4MUP). The concentration of immune reactive insulin present in test sample is directly proportional to the amount of enzyme-labeled monoclonal antibody that binds to the beads. A calibration curve is constructed by using 6 calibrators different known concentrations of insulin (multipoint calibration), and unknown sample concentrations are calculated using this curve.

Iron (CAB): Iron (III) reacts with chrmazurol $\mathrm{B}(\mathrm{CAB})$ and cetyltrimethyl ammonium bromide (CTMA) to form a coloured ternary complex with an absorbance maximum at $623 \mathrm{~nm}$. The intensity of the color produced is directly proportional to the concentration of iron in the sample. The test can also be used in combination with the TIBC kit to determine the total iron binding capacity [28].

TIBC: Saturated and precipitated: The iron-binding protein transferrin in serum is saturated up on treatment with an excess of $\mathrm{Fe}$ (III) ions. Unbound (excess) iron is adsorbed onto aluminum oxide and precipitated. The transferrin-bound iron (TIBC) in the supernatant is then used [29].

Hemoglobin (Hb): Hemoglobin concentration is estimated in whole blood by the cyanide free sodium lauryl sulphate method [30].

Determination of metabolic syndrome: Metabolic syndrome was defined as the respondent's exhibits at least three following investigations criteria: elevated blood pressure, low HDL cholesterol, elevated serum triglycerides, elevated blood glucose, and central obesity.

Calculation HOMA-IR: Insulin resistance was estimated by using the formula of homeostasis model assessment insulin resistance (HOMA-IR fasting insulin $[\mu \mathrm{IU} / \mathrm{ml}] \mathrm{X}$ fasting glucose $[\mathrm{mg} / \mathrm{dl}] / 405$ ), even though this investigation is not a gold standard method for insulin resistance, it correlates with gold standard method. The respondents who had a HOMA score of more than 2.5 were concluded with insulin resistance. Insulin resistance was determined also by triglyceride-toHDL cholesterol ratio [31].

\section{Statistics}

Statistical analysis was performed with SPSS software version 16.0. Data are expressed as the mean+SEM. Results were analyzed statistically by student $\mathrm{t}$ - test, ANOVA, linear regression and Pearson correlation coefficient as appropriate. Statistical significance when $p$ value was less than 0.05 .

\section{Results and Discussion}

In the present study total 1058 subjects were studied in which 187 male participants out 696 showed $26.92 \%$ higher ferritin concentration while 100 female participants out of 362 showed $27.65 \%$ as compared to men (Table 1).

The mean serum ferritin levels (males: $390.3+22.4 \mathrm{ng} / \mathrm{ml}$, Womens: $292+16.8 \mathrm{ng} / \mathrm{ml}$ ) in newly diagnosed type 2 diabetes mellitus were higher compared with the previously diagnosed type 2 diabetes mellitus patients, impaired fasting glucose subjects and healthy subjects represented in Figures 1 and 2.

The result obtained from the present study agree with a previous prospective cohort study of 944 subjects, in which baseline ferritin and transferrin are associated with fasting insulin and HOMA-IR at both base lines 7-year follow-up [32]. Insulin resistance is usually attributed to a defect in insulin action. There is a broad clinical spectrum of insulin resistance; varying from euglycemia (with a notable increase in endogenous insulin) to hyperglycemia Insulin is also responsible for the increased ferritin synthesis in cultured rat glioma cells [33].

This study showed a positive association between serum ferritin concentration and markers of glucose homeostasis in newly diagnosed type 2 diabetes mellitus patients, previously diagnosed type 2 diabetes mellitus patients, impaired fasting glucose subjects and healthy controls. Excess iron could be related to disturbed glucose homeostasis in at least two different ways. Thus initially hypothesis is that serum ferritin would be higher for type 2 diabetes mellitus with insulin resistance than those without it. Firstly, iron deposition in the pancrease can lead to defects in insulin synthesis and secretion [34]. However, in an epidemiological study, insulin secretion responded similarly to the oral glucose load both in the highest and the lowest serum ferritin quantiles, suggesting that modest elevations in body iron levels do not affect the pancreatic capacity to secrete insulin [35]. Secondly, accumulated iron could interfere with the insulin-extracting capacity of the liver resulting in hyperinsulinemia [36]. Iron deposition in the liver may also cause insulin resistance by interfering with the ability of insulin to suppress hepatic glucose production.

In our study, both fasting blood glucose and fasting serum insulin concentrations were elevated at high serum ferritin concentrations. Previous studies also suggested that in addition to the glucose elevation, serum ferritin level might become a surrogate marker of diabetes to predict disease onset $[37,38]$.

\begin{tabular}{|c|c|c|c|}
\hline Characteristic & Sample size (n) & Geometric mean ferritin (ng/ml) & $\begin{array}{l}\text { Percentage with elevated ferritin } \\
\text { concentration }\end{array}$ \\
\hline Total & 1058 & $238.79 \pm 12.8(2-1,979)$ & $(287) 27.285 \pm 2.91$ \\
\hline $\begin{array}{c}\text { Men } \\
\text { Women }\end{array}$ & $\begin{array}{l}696 \\
362\end{array}$ & $\begin{array}{l}279.33 \pm 18.5(3-1.603) \\
198.25 \pm 14.6(2-1.979)\end{array}$ & $\begin{array}{l}(187) 26.925 \pm 3.35 \\
(100) 27.65 \pm 2.475\end{array}$ \\
\hline $\begin{array}{c}\text { Diabetes status } \\
\text { Normal } \\
\text { Men } \\
\text { Women }\end{array}$ & $\begin{array}{l}222 \\
138\end{array}$ & $\begin{array}{c}106.1 \pm 6.2(3-1.698) \\
96.0 \pm 4.2(3-1.404)\end{array}$ & $\begin{array}{l}11.4 \pm 1.1 \\
09.7 \pm 0.9\end{array}$ \\
\hline $\begin{array}{l}\text { Impaired fasting glucose subjects } \\
\text { Men } \\
\text { women }\end{array}$ & $\begin{array}{c}108 \\
81\end{array}$ & $\begin{array}{c}263.3 \pm 11.9(3-1.742) \\
180.3 \pm 9.7(3-1.143)\end{array}$ & $\begin{array}{l}18.2 \pm 2.4 \\
22.6 \pm 1.7\end{array}$ \\
\hline $\begin{array}{l}\text { Newly diagnosed diabetes } \\
\text { Men } \\
\text { women }\end{array}$ & $\begin{array}{l}92 \\
52\end{array}$ & $\begin{array}{c}390.3 \pm 17.9(18-1.137) \\
292.5 \pm 14.2(3-729)\end{array}$ & $\begin{array}{l}44.9 \pm 5.1 \\
48.3 \pm 4.2\end{array}$ \\
\hline $\begin{array}{c}\text { Previously diagnosed diabetes } \\
\text { Men } \\
\text { women }\end{array}$ & $\begin{array}{l}246 \\
119\end{array}$ & $\begin{array}{c}358.05 \pm 17.3(3-1.354) \\
225.5 \pm 13.1(3-1.070)\end{array}$ & $\begin{array}{l}33.2 \pm 4.8 \\
30.7 \pm 3.1\end{array}$ \\
\hline
\end{tabular}

Table 1a: Distributional information of serum ferritin concentration by selected variables among participants aged $\geq 30-65$ years. 


\begin{tabular}{|c|c|c|}
\hline $\begin{array}{c}\text { Diabetes status } \\
\text { Normal } \\
\text { Men } \\
\text { Women }\end{array}$ & $\begin{array}{c}\text { Transferrin saturation }<45 \% \\
<300 \mathrm{ng} / \mathrm{ml} \text { men } \\
<150 \mathrm{ng} / \mathrm{ml} \text { women }\end{array}$ & 1.0 \\
\hline $\begin{array}{l}\text { Impaired fasting glucose subjects } \\
\text { Men } \\
\text { women }\end{array}$ & $\begin{array}{c}\text { Transferrin saturation }<45 \% \\
>300 \mathrm{ng} / \mathrm{ml} \text { men } \\
>150 \mathrm{ng} / \mathrm{ml} \text { women }\end{array}$ & $4.22(2.97-5.99)$ \\
\hline $\begin{array}{c}\text { Newly diagnosed diabetes } \\
\text { Men } \\
\text { women }\end{array}$ & $\begin{array}{c}\text { Transferrin saturation }>45 \% \\
>300 \mathrm{ng} / \mathrm{ml} \text { men } \\
>150 \mathrm{ng} / \mathrm{ml} \text { women }\end{array}$ & $0.30(0.09-1.02)$ \\
\hline $\begin{array}{l}\text { Previously diagnosed diabetes } \\
\text { Men } \\
\text { women }\end{array}$ & $\begin{array}{c}\text { Transferrin saturation }>45 \% \\
<300 \mathrm{ng} / \mathrm{ml} \text { men } \\
<150 \mathrm{ng} / \mathrm{ml} \text { women }\end{array}$ & $1.79(0.60-5.33)$ \\
\hline
\end{tabular}

Table 1b: Odd ratio for four categories in newly diagnosed type-2 diabetes mellitus patients.

The results of mean serum ferritin in healthy, impaired fasting glucose subjects, newly diagnosed, previously diagnosed type 2 Diabetes mellitus patients (Table 2). In our overall research study the mean levels of serum ferritin are significantly lower in premenopausal women $46.5 \mathrm{ng} / \mathrm{ml}$ (95\% CI) compared with postmenopausal women $118.38 \mathrm{ng} / \mathrm{ml}$ and men $187.52 \mathrm{ng} / \mathrm{ml}$ (Table 3 and Figure 3). Comparing from pre menopause to post menopause women, consistent increased ferritin and decreased ratio of serum transferrin ratio (sTfR) ferritin levels. It was also seen that insulin resistance and glucose increased over the menopausal transition was recorded. Women who had the largest changes in their iron (lower measures of iron when they were premenopausal and larger increases in iron measures over the menopausal transition) demonstrated the strongest associations between iron and changes in HOMA-IR.

These findings suggest yet another pathway through which women undergoing the menopausal transition may be at risk for insulin resistance, in addition to unfavorable lifestyle changes and the increasing ratio of androgen: estrogen characterizing menopause [39].

Mean levels of ferritin in newly diagnosed type 2 diabetes (serum ferritin $325.66 \mathrm{ng} / \mathrm{ml}$ ) were positively correlated with mean systolic blood pressure (135.5 mm of $\mathrm{Hg}$ ), and mean fasting insulin $10.93 \mathrm{Uiu} /$ $\mathrm{ml}$ in elderly with metabolic syndrome patients (Table 3; Figure 3).

In previous study, showed a Strong evidence for modification in risk of high ferritin levels by hypertension. Women who had serum ferritin levels $200 \mu \mathrm{g} / \mathrm{L}$ and were hypertensive had a 3.77 fold higher risk of stroke (95\% CI, 1.56 to 9.08) compared with normotensive women who had levels $200 \mu \mathrm{g} / \mathrm{L}$ (304). The generation of superoxide radicals in hypertension has been shown to affect the production and activity of endogenous vascular nitric oxide, which may result in impaired endothelium-dependent vaso-relaxation. Elevated serum $\mathrm{C}$ reactive protein (CRP) and serum ferritin levels with metabolic syndrome and/ or insulin resistance tend to exhibit a certain degree of inflammation that, in one way or another, is likely to increase their risk of developing diabetes mellitus and/or cardiovascular disease. Several cross sectional studies had previously examined showed the association between iron stores and individual metabolic cardiovascular risk factors, including hypertension [40] and central obesity [41].

The mean intake of alcohol was less in all groups in this study, even though there is significant effect of alcohol in previously diagnosed (Group-1), newly diagnosed (Group-2), impaired fasting blood glucose subjects (Group-3) and healthy subjects (Group-4) (Tables 1 and 3) ( $\mathrm{p} \leq 0.001$ ). After adjusting for age, BMI, alcohol intake, C-reactive protein concentration, and examination session attended, men with newly diagnosed diabetes mellitus (Group-1) had an odds ratio of 4.94 (95\% CI 3.05-8.01) and women had an odds ratio of 3.61 (2.01-

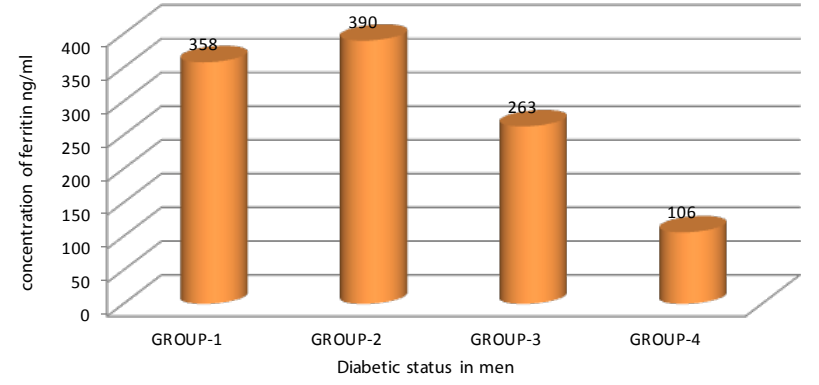

Figure 1: Distribution of mean serum ferritin in Group-1 (Previously Diagnosed type-2 Diabetes mellitus), Group-2 (newly diagnosed type-2) Diabetes mellitus, Group-3 (Impaired fasting glucose subjects) and Group-4 (healthy subjects) of men participants.

\section{women}

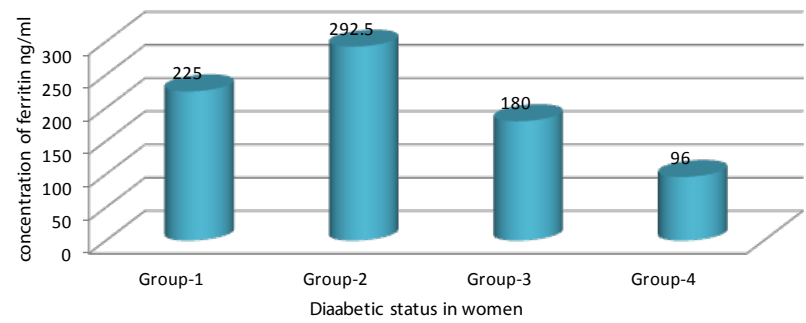

Figure 2: Distribution of mean serum ferritin in Group-1 (previously diagnosed type-2 diabetes mellitus), Group-2 newly diagnosed type-2 diabetes mellitus, Group-3 (impaired fasting glucose subjects) and Group-4 (healthy subjects) of women participants.

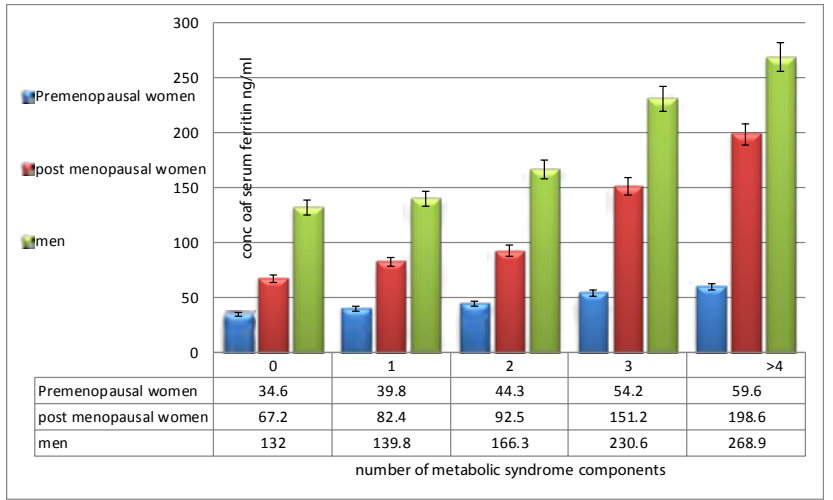

Figure 3: Mean serum ferritin levels in participants with the number of metabolic components.

6.48) regarding having elevated ferritin concentrations as men and women with normal glucose concentrations. The adjusted odds ratios for impaired fasting glucose subjects (Group-3) were 1.35 (0.99-1.83) for all participants, $1.3(0.69-1.85)$ for men, and 1.64 (1.09-2.47) for women. Newly diagnosed diabetes mellitus (Group-2), the interaction term for sex and ferritin concentration was not significant $(\mathrm{p}=0.299)$.

The average participants with type- 2 diabetes mellitus (Group- 1 and Group-2) were older (Figure 3), have higher systolic blood pressure levels, triglyceride concentrations, Glycosylated hemoglobin HbAlc, $\mathrm{BMI}$, and have lower HDL-cholesterol concentration than participants with normal glucose concentrations (Group-4) (Table 3; Figure 4). 
Citation: Sudhakar B, Rita MS (2016) Correlation of Serum Ferritin with Components of Metabolic Syndrome and its Relationship with the Insulin Resistance in Men and Women. Clin Med Biochem 2: 109. doi:10.4172/2471-2663.1000109

Page 5 of 6

Diabetes mellitus status

\begin{tabular}{|c|c|c|c|c|c|}
\hline & $\begin{array}{c}\text { Healthy subjects }{ }^{\star} \text { or } \\
\text { none } \\
\text { Group-4 }\end{array}$ & $\begin{array}{l}\text { Impaired fasting } \\
\text { glucose } \\
\text { (Group-3) }\end{array}$ & $\begin{array}{c}\text { Newly diagnosed type } 2 \\
\text { diabetes } \\
\text { (Group-2) }\end{array}$ & $\begin{array}{c}\text { Previously diagnosed type } 2 \\
\text { diabetes* } \\
\text { (Group-1) }\end{array}$ & $\begin{array}{l}\text { Probability } \\
\text { analysis }\end{array}$ \\
\hline Age (years) & $46.2(1.0)$ & $56.13(0.9) \dagger$ & $59.0(1.0) \dagger$ & $57.9(0.8) \dagger$ & $<0.001$ \\
\hline $\operatorname{Sex}(M / F)$ & $222 / 138$ & $108 / 81$ & $92 / 52$ & $246 / 119$ & \\
\hline Alcohol use (drinks/month) \% & $2.3(0.3)$ & $2.0(0.25) \dagger$ & $2.0(0.72) \dagger$ & $2.2(0.8) \dagger$ & 0.008 \\
\hline Smoker/day & $1.8 \pm 0.4$ & $2.0 \pm 0.50$ & $2.6 \pm 0.9$ & $2.3 \pm 0.7$ & $<0.001$ \\
\hline BMI (kg/m2) & $20.66 \pm 2.13$ & $23.83 \pm 2.71$ & $33.53 \pm 4.66$ & $30.26 \pm 3.48$ & $<0.001$ \\
\hline $\begin{array}{l}\text { Systolic blood pressure } \\
(\mathrm{mmHg})\end{array}$ & $117.5(0.4)$ & $132.8(1.1) \dagger$ & $135.5(1.5) \dagger$ & $131.7(1.8) \dagger$ & $<0.001$ \\
\hline Fasting blood glucose $(\mathrm{mg} / \mathrm{dl})$ & $84 \pm 6.3$ & $119 \pm 12.0$ & $165.6 \pm 16.4$ & $142.5 \pm 14.7$ & $<0.001$ \\
\hline serum ferritin $(\mathrm{ng} / \mathrm{ml})$ & $100.6 \pm 2$ & $207.6(0.04) \dagger$ & $325.66(0.02) \dagger$ & $270.33(0.01) \dagger$ & $<0.001$ \\
\hline Serum insulin $u U / m l$ & $5.8 \pm 0.88$ & $7.55 \pm 1.07$ & $10.93 \pm 2.93$ & $8.81 \pm 2.46$ & $<0.001$ \\
\hline Total cholesterol (mg/dl) & $140.50 \pm 15.12$ & $182.6 \pm 22.56$ & $238.3 \pm 30.7$ & $219.40 \pm 29.21$ & $<0.001$ \\
\hline HDL cholesterol (mg/dl) & $51.08 \pm 4.2$ & $45.38 \pm 5.8(0.02) \dagger$ & $38.2 \pm 8.86(0.03) \dagger$ & $39.47 \pm 6.75(0.03) \dagger$ & $<0.001$ \\
\hline Triglycerides (mg/dl) & $116 \pm 15$ & $143.6 \pm 16.8$ & $188 \pm 18.3$ & $156.33 \pm 20.23$ & $<0.001$ \\
\hline HOMA -IR & $1.26(0.79-1.75)$ & $2.22(2.9-3.95)$ & $4.4(2.4-6.4)$ & $3.15(2.07-4.07)$ & $<0.001$ \\
\hline $\mathrm{HbA1C}$ & $5.2 \pm 0.2$ & $5.9 \pm 0.4$ & $12.8 \pm 1.2$ & $8.93 \pm 0.75$ & $<0.001$ \\
\hline Transferrin saturation \% & $28.9(0.3)$ & $26.7(0.5) \dagger$ & $24.5(0.8)$ & $26.23(0.8)$ & $<0.001$ \\
\hline TGL/HDL-C ratio & $2.156 \pm 0.4$ & $3.18 \pm 0.6$ & $4.94 \pm 1.2$ & $3.96 \pm 0.8$ & $<0.001$ \\
\hline
\end{tabular}

Data are means $\pm S E M$ * maximum sample size $\dagger P$ values $<0.05$ compared with participants with normal glucose tolerance.

Table 2: Unadjusted mean of serum ferritin, metabolic syndrome components and insulin resistance syndrome (HOMA-IR) among the participants aged $\geq 30$ years.

\begin{tabular}{|c|c|c|c|}
\hline $\begin{array}{c}\text { Components of metabolic } \\
\text { syndrome }\end{array}$ & $\begin{array}{c}\text { Premenopausal women Mean serum ferritin } \\
\mathbf{n g} / \mathbf{m l}\end{array}$ & $\begin{array}{c}\text { postmenopausal women Mean serum ferritin } \\
\text { ng/ml }\end{array}$ & $\begin{array}{c}\text { Men Mean serum ferritin } \\
\mathbf{n g} / \mathbf{m l}\end{array}$ \\
\hline 0 & 34.6 & 67.2 \\
\hline 1 & 39.8 & 82.4 \\
\hline 2 & 44.3 & 92.5 \\
\hline 3 & 54.2 & 132 \\
\hline$>4$ & 59.6 & 151.2 \\
\hline Total Mean ferritin & 46.5 & 198.6 \\
\hline
\end{tabular}

Table 3: Geometric mean values of serum ferritin are shown for premenopausal women (blue bar), postmenopausal women (red bar), and men (gray bar). Errors represent upper $95 \% \mathrm{Cl}$. The trend of increasing mean ferritin values across categories of metabolic syndrome components was significant in all three group ( $p<0.05$ ).

DIABETES STATUS AS PER AGE GROUP

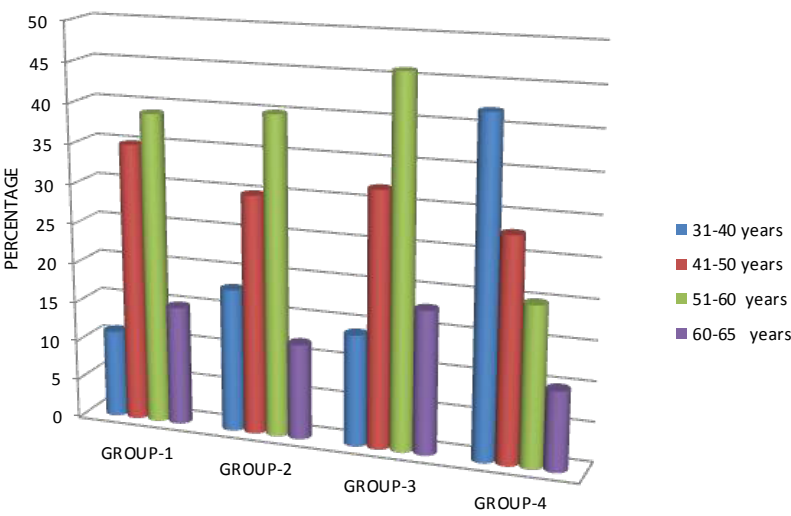

DIABETES STATUS

Figure 4: Distribution of previously diagnosed type-2 diabetes, newly diagnosed type-2 diabetes mellitus patients impaired fasting glucose and healthy subjects as per age group

\section{Conclusion}

It was concluded that elevated ferritin levels and serum CRP show that patients with MS and/or insulin resistance tend to exhibit a certain degree of inflammation that, in one way or another, is likely to increase their risk of developing diabetes /or cardiovascular disease. Determination of the serum CRP and ferritin concentrations of patients with MS and/or insulin resistance might thus aid their evaluation as candidates for aggressive intervention against pre-diabetes or risk for development of diabetes mellitus andcardiovascular risk factors. Serum ferritin along with the CRP and WBC cellsserves as important indicator to monitorinsulin resistance in Impaired fasting glucose subjects/ prediabetes before onset to type 2 diabetes. In respondents with $>11.5 \mathrm{Hb} \%$ concentration, Serum ferritin can be suggested as routine biochemical investigation along with fasting blood sugar by adjusting with CRP and WBC cells.

\section{Acknowledgements}

I am extremely grateful and thankful to Dr. Rita M Shah, Professor and Head of the Department of Biochemistry, SBKSMI and RI, an outstanding teacher, mentor and motivator for her thoughtful suggestions, comments and encouragement that have been of immense help.

\section{References}

1. Wild S, Roglic G, Green A, Sicree R, King H (2004) Global prevalence of diabetes: estimates for the year 2000 and projections for 2030. Diabetes Care 27: 1047-1053.

2. International Diabetes Federation (2009) IDF Diabetes Atlas. 4th edn. Brussels: International Diabetes Federation.

3. Ramachandran A, Snehalatha C, Kapur A, Vijay V, Mohan V, et al. (2001) High prevalence of diabetes and impaired glucose tolerance in India: National Urban Diabetes Survey. Diabetologia 44: 1094-1101. 
Citation: Sudhakar B, Rita MS (2016) Correlation of Serum Ferritin with Components of Metabolic Syndrome and its Relationship with the Insulin Resistance in Men and Women. Clin Med Biochem 2: 109. doi:10.4172/2471-2663.1000109

Page 6 of 6

4. Mohan V, Sandeep S, Deepa R, Shah B, Varghese C (2007) Epidemiology of type 2 diabetes: Indian scenario. Indian J Med Res 125: 217-230.

5. Witte DL, Crosby WH, Edwards CQ, Fairbanks VF, Mitros FA (1996) Practice guideline development task force of the College of American Pathologists. Hereditary hemochromatosis. Clin Chim Acta 245: 139-200.

6. McCord JM (1996) Effects of positive iron status at a cellular level. Nutr Rev 54: 85-88.

7. Beard JL (2001) Iron biology in immune function, muscle metabolism and neuronal functioning. J Nutr 131: 568S-579S.

8. Oberley LW (1988) Free radicals and diabetes. Free Radic Biol Med 5: 113124

9. Wolff SP (1993) Diabetes mellitus and free radicals. Free radicals, transition metals and oxidative stress in the aetiology of diabetes mellitus and complications. Br Med Bull 49: 642-652.

10. Ford ES, Cogswell ME (1999) Diabetes and serum ferritin concentration among U.S. adults. Diabetes Care 22: 1978-1983

11. Tuomainen TP, Nyyssönen K, Salonen R, Tervahauta A, Korpela H, et al (1997) Body iron stores are associated with serum insulin and blood glucose concentrations. Population study in 1,013 eastern Finnish men. Diabetes Care 20: $426-428$

12. Fernández-Real JM, Ricart-Engel W, Arroyo E, Balançá R, CasamitjanaAbella R, et al. (1998) Serum ferritin as a component of the insulin resistance syndrome. Diabetes Care 21: 62-68.

13. Hughes K, Choo M, Kuperan P, Ong CN, Aw TC (1998) Cardiovascular risk factors in non-insulin-dependent diabetics compared to non-diabetic controls: a popu population-based survey among Asians in Singapore. Atherosclerosis 136: 25-31.

14. Kim NH, Oh JH, Choi KM, Kim YH, Baik SH, et al. (2000) Serum ferritin in healthy subjects and type 2 diabetic patients. Yonsei Med J 41: 387-392.

15. Hernández C, Genescà J, Ignasi Esteban J, García L, Simó R (2000) Relationship between iron stores and diabetes mellitus in patients infected by hepatitis C virus: a case-control study. Med Clin (Barc) 115: 21-22.

16. Fernández-Real JM, López-Bermejo A, Ricart W (2002) Cross-talk between iron metabolism and diabetes. Diabetes 51: 2348-2354

17. Veiga $F$, Fernandes $C$, Teixeira $F(2000)$ Oral bioavailability and hypoglycaemic activity of tolbutamide/cyclodextrin inclusion complexes. Int J Pharm 202: 165171.

18. Cook JD, Lipschitz DA, Miles LE, Finch CA (1974) Serum ferritin as a measure of iron stores in normal subjects. Am J Clin Nutr 27: 681-687.

19. Walters GO, Miller FM, Worwood M (1973) Serum ferritin concentration and iron stores in normal subjects. J Clin Pathol 26: 770-772.

20. Engbaek F, Christensen SE, Jespersen B (1989) Enzyme immunoassay of hemoglobin A1c: analytical characteristics and clinical performance for patients with diabetes mellitus, with and without uremia. Clin Chem 35: 93-97.

21. MacLachlan J, Wotherspoon AT, Ansell RO, Brooks CJ (2000) Cholestero oxidase: sources, physical properties and analytical applications. J Steroid Biochem Mol Biol 72: 169-195.

22. Richmond W (1973) Preparation and properties of a cholesterol oxidase from Nocardia sp. and its application to the enzymatic assay of total cholesterol in serum. Clin Chem 19: 1350-1356.

23. Stein EA, Myers GL (1994) Lipids, Lipoproteins and Apolipoproteins in Tietz Textbook of clinical chemistry. Buritis CA and Ashwood ER (Ed). WB Saunders Company, 2nd edn. pp: 1002-1093.

Citation: Sudhakar B, Rita MS (2016) Correlation of Serum Ferritin with Components of Metabolic Syndrome and its Relationship with the Insulin Resistance in Men and Women. Clin Med Biochem 2: 109. doi:10.4172/2471-2663.1000109
24. Product Data Sheet, Triglycerides-G Code NO 997-69801, Wako Pure chemical Industries Ltd. Dallas TX

25. Barr DP, Russ EM, Eder HA (1951) Protein-lipid relationships in human plasma II. In atherosclerosis and related conditions. Am J Med 11: 480-493.

26. Gordon T, Castelli WP, Hjortland MC, Kannel WB, Dawber TR (1977) High density lipoprotein as a protective factor against coronary heart disease. The Framingham Study. Am J Med 62: 707-714.

27. Williams $P$, Robinson D, Bailey A (1979) High-density lipoprotein and coronary risk factors in normal men. Lancet 1: 72-75.

28. Callahan JH, Cook KO (1982) Modified CMB Method of Iron estimation in serum. Anal Chem 54: 59-62.

29. Tietz NW (2006) Clinical Guide to Laboratory Tests. 4th edn. Philadelphia: WB Saunders Co. p: 392.

30. Oshiro I, Takenaka T, Maeda J (1982) New method for hemoglobin determination by using sodium lauryl sulfate (SLS). Clin Biochem 15: 83-88.

31. Nolan JJ, Jones NP, Patwardhan R, Deacon LF (2000) Rosiglitazone taken once daily provides effective glycaemic control in patients with Type 2 diabetes mellitus. Diabet Med 17: 287-294.

32. Yokomori N, Iwasa Y, Aida K, Inoue M, Tawata M, et al. (1991) Transcriptiona regulation of ferritin messenger ribonucleic acid levels by insulin in cultured rat glioma cells. Endocrinology 128: 1474-1480

33. Felber JP, Ferrannini E, Golay A, Meyer HU, Theibaud D, et al. (1987) Role of lipid oxidation in pathogenesis of insulin resistance of obesity and type II diabetes. Diabetes 36: 1341-1350.

34. DeFronzo RA (1988) Lilly lecture 1987. The triumvirate: beta-cell, muscle, liver A collusion responsible for NIDDM. Diabetes 37: 667-687.

35. Niederau C, Berger M, Stremmel W, Starke A, Strohmeyer G, et al. (1984) Hyperinsulinaemia in non-cirrhotic haemochromatosis: impaired hepatic insulin degradation? Diabetologia 26: 441-444.

36. Forouhi NG, Harding AH, Allison M, Sandhu MS, Welch A, et al. (2007) Elevated serum ferritin levels predict new-onset type 2 diabetes: results from the EPIC-Norfolk prospective study. Diabetologia 50: 949-956.

37. Rajpathak SN, Wylie-Rosett J, Gunter MJ, Negassa A, Kabat GC, et al. (2009) Biomarkers of body iron stores and risk of developing type 2 diabetes. Diabetes Obes Metab 11: 472-479.

38. Sternfeld B, Wang H, Quesenberry CP Jr, Abrams B, Everson-Rose SA, et al. (2004) Physical activity and changes in weight and waist circumference in midlife women: findings from the Study of Women's Health Across the Nation. Am J Epidemiol 160: 912-922.

39. Torrens J, Sutton-Tyrrell K, Zhao X (2009) Relative androgen excess during the menopausal transition predicts incident metabolic syndrome in midlife women: Study of Women's Health across the Nation. Menopause 16: 257-264.

40. Piperno A, Trombini P, Gelosa M, Mauri V, Pecci V, et al. (2002) Increased serum ferritin is common in men with essential hypertension. J Hypertens 20 1513-1518.

41. Gillum RF (2001) Association of serum ferritin and indices of body fat distribution and obesity in Mexican American men--the Third National Health and Nutrition Examination Survey. Int J Obes Relat Metab Disord 25: 639-645.

\section{OMICS International: Publication Benefits \& Features} Unique features:

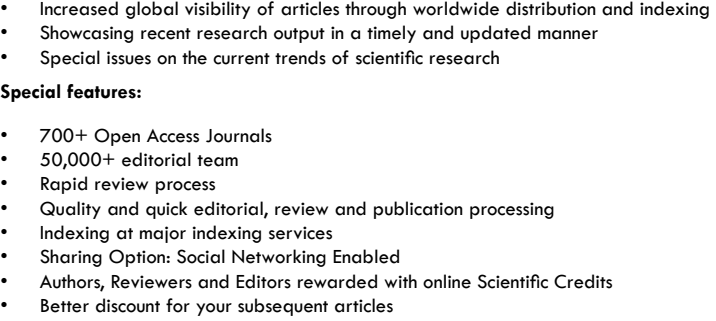

